IZA DP No. 6767

Identifying Regional Labor Demand Shocks

Using Sign Restrictions

Falko Juessen

Ludger Linnemann

July 2012 


\title{
Identifying Regional Labor Demand Shocks Using Sign Restrictions
}

\author{
Falko Juessen \\ TU Dortmund University \\ and IZA \\ Ludger Linnemann \\ TU Dortmund University
}
Discussion Paper No. 6767
July 2012

IZA
P.O. Box 7240
53072 Bonn
Germany

Phone: +49-228-3894-0

Fax: +49-228-3894-180

E-mail: iza@iza.org

\begin{abstract}
Any opinions expressed here are those of the author(s) and not those of IZA. Research published in this series may include views on policy, but the institute itself takes no institutional policy positions.

The Institute for the Study of Labor (IZA) in Bonn is a local and virtual international research center and a place of communication between science, politics and business. IZA is an independent nonprofit organization supported by Deutsche Post Foundation. The center is associated with the University of Bonn and offers a stimulating research environment through its international network, workshops and conferences, data service, project support, research visits and doctoral program. IZA engages in (i) original and internationally competitive research in all fields of labor economics, (ii) development of policy concepts, and (iii) dissemination of research results and concepts to the interested public.
\end{abstract}

IZA Discussion Papers often represent preliminary work and are circulated to encourage discussion. Citation of such a paper should account for its provisional character. A revised version may be available directly from the author. 
IZA Discussion Paper No. 6767

July 2012

\section{ABSTRACT \\ Identifying Regional Labor Demand Shocks Using Sign Restrictions}

We propose using sign restrictions to identify regional labor demand shocks in a panel VAR of US federal states. Observed migration responds significantly, but less persistently than the residual-based migration measure constructed by Blanchard and Katz (1992).

JEL Classification: E24, R11, C33, C32

Keywords: regional labor markets, migration, panel VAR, sign restrictions

Corresponding author:

Ludger Linnemann

TU Dortmund

Department of Economics

Vogelpothsweg 87

44221 Dortmund

Germany

E-mail: ludger.linnemann@tu-dortmund.de 


\section{Introduction}

In a seminal paper, Blanchard and Katz (1992, BK henceforth) estimated the effects of region-specific shocks to labor demand in US states on unemployment, labor force participation, and a residual interpreted as population change mainly due to regional migration. While their approach has since been used by many other authors ${ }^{2}$, two aspects of the BK approach are potentially problematic: first, identification of labor demand shocks relies on restrictive assumptions, and, second, the migration response is measured only as a residual.

In this paper, we analyze annual US state-level labor market fluctuations during 1989-2009 and contribute as follows. First, we identify labor demand and supply shocks directly using a sign-restrictions approach (see Fry and Pagan 2011 for a survey on sign restrictions). Second, we use observed data on state-level migration instead of measuring migration residually. Third, we use a bias-corrected estimator for the panel VAR that is particularly suited when the time dimension of the panel is short.

With respect to identification, BK assume that year-to-year changes in employment are entirely due to labor demand shocks, which they impose by ordering employment first in a recursively identified panel vector autoregression. ${ }^{3}$ However, a priori it is unclear how strongly employment is contemporaneously affected by regional labor supply shocks due to participation or net migration changes. We therefore propose to identify regional labor demand shocks non-recursively by using the sign restrictions on panel VAR impulse responses that labor demand shocks (e.g. due to region-specific technology shocks) should move regional employment and real wages (in terms of producer prices) in the same direction, whereas labor supply shocks should lead to opposite movements in these variables. Thus, the sign of the real wage response can identify shifts in labor demand. With respect to migration, BK treat all residual employment changes not accounted for by unemployment or participation changes as being due to migration. This migration residual may however also pick up other factors, such as natural population change. We therefore use observed migration data, which fits well with our non-recursive identification approach that does not rule out contemporaneous effects of net migration on regional employment.

\footnotetext{
${ }^{2}$ See for instance Decressin and Fatas (1995), Fredriksson (1999), Obstfeld and Perri (2000), Tani (2003), Mäki-Arvela (2003), Gács and Huber (2005), and Partridge and Rickman (2006).

${ }^{3}$ Actually, BK use employment growth, while we focus on employment levels. We have verified the robustness of our results to specifying employment in growth rates.
} 
In line with previous studies, we find that migration is an important adjustment mechanism to region-specific shocks in the US. On impact, migration smoothes about $25 \%$ of an idiosyncratic shock to labor demand. The estimated migration response is however less persistent than the residual-based migration measure constructed by BK. Quantitatively, the most important absorbers of labor demand shocks are the decline in the unemployment rate and the increase in the participation rate.

\section{Data, estimation, and identification}

We use annual data on the 48 contiguous US states (excluding Alaska, Hawai, and DC) from 1989-2009. The total number of observations is 1,008. The web appendix contains a detailed description of data sources and definitions. The variables used in the panel VAR are log employment, the unemployment rate, and the log participation rate (as in BK and the subsequent literature), and additionally the state-level net migration rate provided by the Internal Revenue Service (IRS) and a measure of the real wage rate. ${ }^{4}$ For our identification approach, it is important to measure the real wage in terms of producer prices (the consumption-based real wage could change due to import price variations unrelated to local labor demand). We therefore construct the real wage rate by deflating labor compensation per employed person with GDP prices, obtained as the ratio of nominal to real GDP.

In the panel VAR, we include regional fixed effects as well as time-specific effects common to all regions. Thus, region-specific means as well as aggregate influences common to all states are controlled for. We use two lags on each variable (we checked that the results are robust to using one or three lags) and control for linear state-specific trends.

Since least squares estimators of dynamic panels with fixed effects are known to be biased in short samples (see Nickell 1981 and Judson and Owen 1999 for Monte Carlo evidence), we use a bias-corrected estimator developed by Hahn and Kuersteiner (2002). In the practical implementation, we impose blockwise zero and identity restrictions on the slope coefficients to allow for higher-order dynamics (we use two lags).

We implement sign restrictions through a Householder transformation (the web appendix provides technical details). The impulse responses are kept if they jointly satisfy the conditions for labor demand and supply shocks, respectively: in response

\footnotetext{
${ }^{4}$ See Bayer and Juessen (2012) for a discussion on the IRS migration data.
} 
to a labor demand shock, the real wage and employment should move in the same direction, while a labor supply shock should result in wage and employment changes of opposite signs. It turned out that our results are not very sensitive to the horizon at which the sign restrictions are imposed; in our baseline specification we impose the restrictions in the impact period and the following two years. The procedure is repeated until 50,000 valid responses are found.

\section{Results}

Figure 1 summarizes the median impulse responses following a $1 \%$ positive shock to labor demand, identified using sign restrictions (the shaded areas show the 16th and 84th percentiles of the accepted responses). ${ }^{5}$ For comparison, the dashed lines also display the results obtained using a recursive identification as in BK with employment ordered first (the dotted lines are $90 \%$ bootstrap confidence bounds).

While BK motivate their identification procedure by pointing out that real wages do tend to increase after a recursively identified employment shock, we find using our more recent data set that the real wage rate would initially decline after a recursively identified positive labor demand shock, see the first panel in Figure 1. Thus, the recursive approach may well estimate an average of labor demand and supply shocks in which the tendency to decrease wages happens to dominate. ${ }^{6}$ By constrast, in our approach using sign restrictions the positive comovement of real wages is used as the identifying restriction to isolate labor demand shocks (and vice versa for labor supply shocks).

With respect to the other responses, one can see that the two different identification strategies yield quantitatively different but not contradictory results. We first perform a statistical test to see whether the differences visible in Figure 1 are statistically significant. For this, we draw bootstrap samples, re-estimate the panel VAR, and calculate the difference between the Cholesky IRFs and the median IRFs obtained using sign restrictions. For the first three years after the shock, Table 1 reports the average difference and standard errors are in parentheses. According to the test, most of the responses are significantly different in the impact period and also at later horizons. In particular, the impact response of the net migration

\footnotetext{
${ }^{5}$ Note that the shaded areas do not have the usual interpretation of confidence bands (reflecting sampling uncertainty) but refer to a distribution across models, see Fry and Pagan (2011). We checked that the median responses are similar to the ones from a median target model, where all responses are taken from a single draw.

${ }^{6}$ Fredriksson (1999) criticizes the recursive identification on the same grounds and uses an instrumental variable approach on Swedish data.
} 

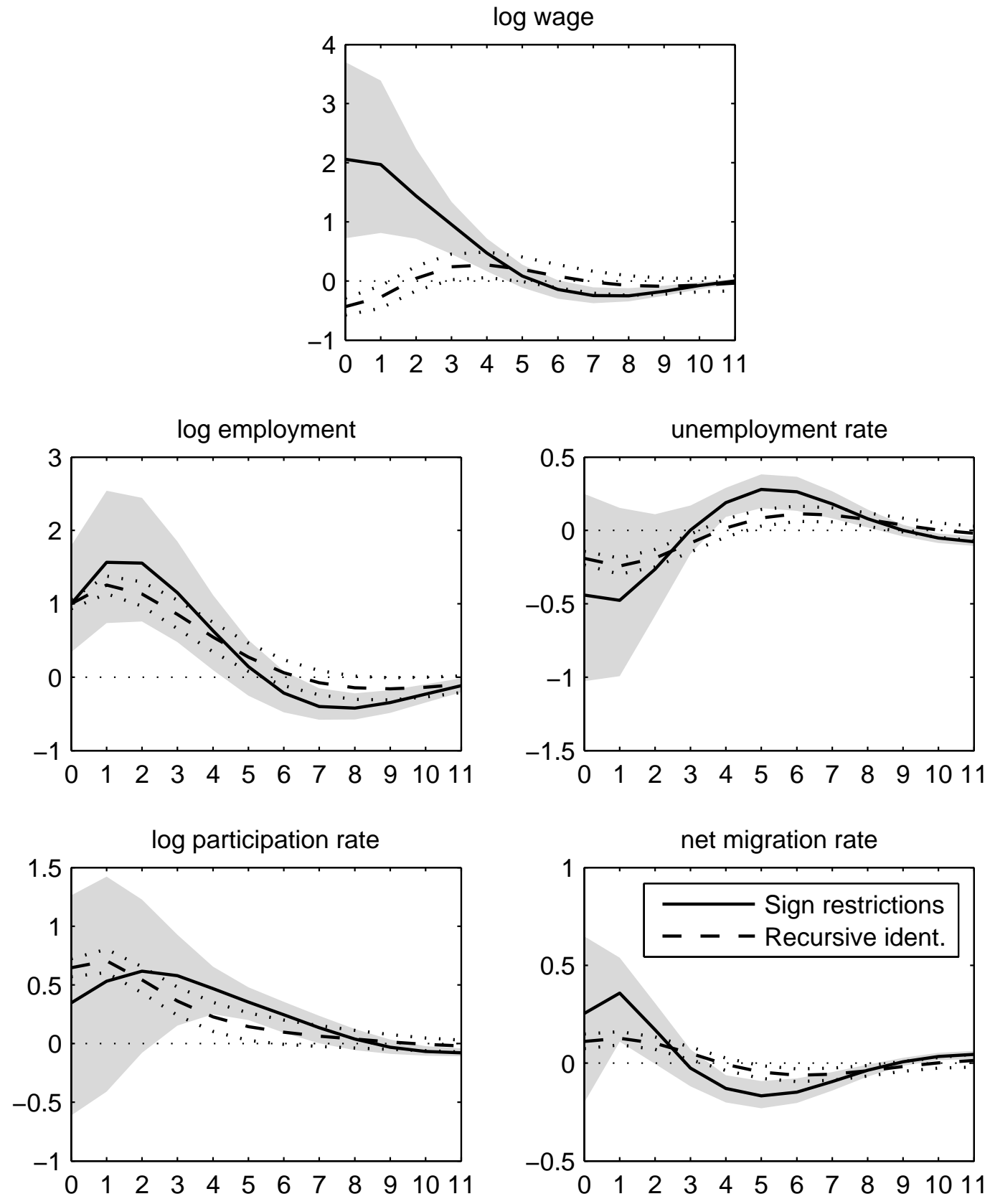

Figure 1: Summary of impulse response to a one percent shock to labor demand. 
rate differs significantly, with recursive identification under-estimating the increase in net migration.

Under our preferred identification using sign restrictions, we find that the decline in the unemployment rate absorbs about $45-50 \%$ of the employment shock in the short run. The participation response is rather persistent and also accomodates a fairly large component of the shock, so that unemployment and participation are the main absorbers of a typical labor demand shock in the US. We confirm previous evidence for the US that interstate migration is an important adjustment mechanism. Yet, the short-run increase in the net migration rate is with $25-30 \%$ smaller than reported in e.g. BK's original study. In particular, we find that the migration rate returns to its initial level after about fours years, at a time when the effect of the labor demand shock is still positive.

We can compare these results to Obstfeld and Perri (2000), who have updated the original BK US data sample to 1995 (BK's sample ends in 1990). Similar to our results, they document an impact response of the participation rate of 0.43 and the residual migration response is 0.33 on impact. However, we find the migration response estimated from observed migration data to be less persistent than their migration residual.

We have performed a number of sensitivity checks three of which are detailed in the web appendix. ${ }^{7}$ First, we estimated a specification where employment enters in first-differences. Second, we entered in- and outmigration rates separately instead of using the net migration rate. Third, we estimated the panel VAR using a simple fixed effects estimator. Overall, we find our results to be robust.

\section{Conclusion}

We have used sign restrictions to identify regional labor demand shocks in a panel VAR of US federal states. Observed migration responds significantly, but less persistently than the residual-based migration measure constructed by Blanchard and Katz (1992). The main absorbers of a typical labor demand shock in the US are unemployment and participation.

\footnotetext{
${ }^{7}$ Further sensitivity checks are available on request.
} 


\begin{tabular}{|c|c|c|c|c|}
\hline Variable & Horizon & Recursive & Sign Restr. & Difference \\
\hline \multirow[t]{6}{*}{ Log employment } & \multirow[t]{2}{*}{ Impact } & 1.00 & "1.00 & $\overline{0.00}$ \\
\hline & & $(0.00)$ & $(0.00)$ & $(0.00)$ \\
\hline & \multirow[t]{2}{*}{1} & 1.23 & 1.55 & -0.32 \\
\hline & & $(0.04)$ & $(0.07)$ & $(0.06)$ \\
\hline & \multirow[t]{2}{*}{2} & 1.08 & 1.51 & -0.44 \\
\hline & & $(0.07)$ & $(0.13)$ & $(0.10)$ \\
\hline \multirow[t]{6}{*}{ Unemployment rate } & \multirow[t]{2}{*}{ Impact } & -0.19 & -0.46 & 0.26 \\
\hline & & $(0.02)$ & $(0.06)$ & $(0.05)$ \\
\hline & \multirow[t]{2}{*}{1} & -0.24 & -0.48 & 0.24 \\
\hline & & $(0.03)$ & $(0.06)$ & $(0.06)$ \\
\hline & \multirow[t]{2}{*}{2} & -0.18 & -0.26 & 0.08 \\
\hline & & $(0.03)$ & $(0.06)$ & $(0.05)$ \\
\hline \multirow[t]{6}{*}{ Log participation rate } & \multirow[t]{2}{*}{ Impact } & 0.65 & 0.31 & 0.34 \\
\hline & & $(0.03)$ & $(0.07)$ & $(0.06)$ \\
\hline & \multirow[t]{2}{*}{1} & 0.69 & 0.49 & 0.20 \\
\hline & & $(0.05)$ & $(0.10)$ & $(0.08)$ \\
\hline & \multirow[t]{2}{*}{2} & 0.51 & 0.57 & -0.06 \\
\hline & & $(0.06)$ & $(0.11)$ & $(0.09)$ \\
\hline \multirow[t]{6}{*}{$\overline{\text { Log wage }}$} & \multirow[t]{2}{*}{ Impact } & -0.43 & 2.09 & -2.53 \\
\hline & & $(0.07)$ & $(0.18)$ & $(0.20)$ \\
\hline & \multirow[t]{2}{*}{1} & -0.26 & 1.97 & -2.23 \\
\hline & & $(0.10)$ & $(0.19)$ & $(0.21)$ \\
\hline & \multirow[t]{2}{*}{2} & 0.06 & 1.40 & -1.34 \\
\hline & & $(0.12)$ & $(0.23)$ & $(0.22)$ \\
\hline \multirow[t]{6}{*}{ Net migration rate } & \multirow[t]{2}{*}{ Impact } & 0.11 & 0.26 & -0.15 \\
\hline & & $(0.02)$ & $(0.05)$ & $(0.04)$ \\
\hline & \multirow[t]{2}{*}{1} & 0.12 & 0.36 & -0.24 \\
\hline & & $(0.02)$ & $(0.04)$ & $(0.03)$ \\
\hline & \multirow[t]{2}{*}{2} & 0.10 & 0.16 & -0.07 \\
\hline & & $(0.02)$ & $(0.04)$ & (0.03) \\
\hline
\end{tabular}

Standard errors in parentheses.

Table 1: Bootstrap test for significant differences. 


\section{References}

Bayer, Christian and Falko Juessen (2012), On the Dynamics of Interstate Migration: Migration Costs and Self-Selection, Review of Economic Dynamics, 15, 3, 377-401.

Blanchard, Olivier and Lawrence F. Katz (1992), Regional Evolutions, Brookings Papers on Economic Activity, 1, 1-75.

Decressin, Jörg and Antonio Fatas (1995), Regional labor market dynamics in Europe, European Economic Review, 39, 9, 1627-1655.

Fredriksson, Peter (1999), The dynamics of regional labor markets and active labor market policy: Swedish evidence, Oxford Economic Papers, 51, 4, 623-648.

Gács, Vera and Peter Huber (2005), Quantity adjustments in the regional labour markets of EU candidate countries, Papers in Regional Science, 84, 4, 553-574.

Judson, Ruth A and Ann L. Owen (1999), Estimating dynamic panel data models: a guide for macroeconomists, Economics Letters, 65, 1, 9-15.

Mäki-Arvela, Petteri (2003), Regional Evolutions in Finland: Panel Data Results of a VAR Approach to Labour Market Dynamics, Regional Studies, 37.5, 423-443.

Obstfeld, Maurice and Giovanni Peri (2000), Intranational Migration: Business Cycles and Growth, in: Intranational Macroeconomics, Eds. Eric van Wincoop and Greg Hess. Cambridge University Press, 221-271.

Partridge, Mark D. and Dan S. Rickman (2006), An SVAR Model of Fluctuations in U.S. Migration Flows and State Labor Market Dynamics, Southern Economic Journal, 72, 4, 958-980.

Tani, Massimiliano (2003), Have Europeans become more mobile? A note on regional evolutions in the EU: 1988-1997, Economics Letters, 80, 23-30. 